\title{
Prevalence of Extended-spectrum and AmpC Beta-lactamases Producing STEC in Bovine Diarrhoea Cases in West Bengal, India
}

\author{
Kunal Batabyal", Achintya Mahanti, Samir Dey, Siddhartha Narayan Joardar, \\ Indranil Samanta, Devi Prasad Isore, Abhiroop Banerjee and Abhishek Dharm Singh
}

Department of Veterinary Microbiology, Faculty of Veterinary and Animal Sciences, West Bengal University of Animal and Fishery Sciences, Kolkata - 37, West Bengal, India

*Corresponding author

\begin{tabular}{l} 
K e y w o r d s \\
$\begin{array}{l}\text { Antibiogram, } \\
\text { ACBL, Bovine } \\
\text { diarrhoea, ESBL, } \\
\text { eae A, Escherichia } \\
\text { coli, STEC }\end{array}$ \\
\hline $\begin{array}{l}\text { Article Info } \\
\text { Accepted: } \\
\text { 04 September } 2020 \\
\text { Available Online: } \\
\text { 10 October } 2020\end{array}$ \\
\hline
\end{tabular}

\section{A B S T R A C T}

Escherichia coli are important commensal with pathogenic potentiality in bovine neonates and may cause intestinal and extra-intestinal infections. Different enteric pathogens such as $E$. coli may remain associated with bovine diarrhoea which is a multifactorial menace. Possession of antimicrobial resistance genes by these commensal or pathogens associated with diarrhea makes the issue more serious. The study was aimed to detect the occurrence and characterize extended-spectrum (ESBL) and AmpC (ACBL) beta-lactamases producing pathogenic E. coli (STEC) in diarrhoeal faecal samples collected from bovines. All the $E$. coli strains $(13 / 21,61.9 \%)$ isolated from bovine diarrhoea cases $(n=21)$ were found to be ESBL producers. In total, $11(84.6 \%)$ isolates were positive in cefoxitincloxacillin double-disc synergy (CC-DDS) test for AmpC production and the isolates were also confirmed by PCR for $b l a_{\mathrm{AmpC}}$. Any of the $E$. coli isolates were not carrying the class I integrons but $7(53.8 \%)$ of those isolates were found to possess theSTEC gene, eaeA (responsible for causing diarrhoea) as revealed in PCR assays. All the ESBL producing E. coli isolates showed a high level of resistance to amoxicillin/clavulanic acid, ceftriaxone, ceftazidime, ampicillin/cloxacillin, cefotaxime, cefepime, cefoperazone (100\%), cefoxitin $(84.6 \%)$ and tetracycline $(61.5 \%)$ whereas Ertapenem $(92.3 \%)$, and enrofloxacin $(84.6 \%)$ were intermediately sensitive against these pathogens. All the isolates were susceptible to amikacin, levofloxacin, gentamicin, ampicillin/sulbactam, and doxycycline.

\section{Introduction}

Neonatal Calf Diarrhoea/bovine diarrhoea is a multifactorial syndrome including pathogen (infectious NCD) as well as non-infectious factors related to the host (immunological and nutritional status), the environment and the management (Izzo et al., 2011). Because of the multifactorial nature of NCD, E. coli is one of the causes, is difficult to control effectively (Cho and Yoon, 2014).

Enterotoxigenic E. coli (ETEC) are considered as the most common E. coli pathotype associated with NCD and the strains produce K99 (F5) adhesin and heatstable (STa or STb) and/or heat-labile (LT1 or LT2) enterotoxins (Kaper et al., 2004). The 
ETEC causes watery diarrhoea and weakness in 1-4days old newborn calves. Death usually occurs within 24 hours of infection due to severe dehydration (Cho et al., 2010). The fimbrial adhesin F5 (K99) promotes the adhesion of bacterial cells to glycoproteins on the epithelial surface of the jejunum and/or ileum, and bacterial enterotoxins cause damage to the epithelial cells, resulting in fluid secretion and subsequently the diarrhoea (Acres, 1985). Shiga toxin-producing Escherichia coli (STEC) and Enterohemorrhagic Escherichia coli (EHEC) are also dreadful animal pathogens causing the infection through food and water leading to gastrointestinal infections and bloody diarrhoea in bovines (Hickey et al., 2015; Nguyen and Sperandio, 2012).

Many STEC also produces intimin, an outer membrane surface adhesin encoded by the chromosomal eaeA gene with several variants found in the pathogenicity island (locus of enterocyte effacement [LEE]) responsible for causing bloody diarrhoea in calves (Blanco et al., 2004). Enterotoxigenic Escherichia coli (ETEC) can cause bovine infections leading to diarrhoea with morbidity and mortality loss throughout the world (Izzo et al., 2011; Acha et al., 2004).

The possession of antimicrobial resistance genes like the genes encoding ESBL and ACBL in $E$. coli strains is the growing concern in the globe including India. The pathogens carrying the resistance genes pose a major challenge for the treatment of infections as the enzymes encoded make the pathogen resistant to higher generation of cephalosporins (Tenover et al., 1999). Consequently, there is an increase in the use of last-resort antimicrobial drugs (i.e. carbapenems) for treatment. Again, E. coli strains carrying the resistance genes can easily transfer those genes to other pathogens leading to the spread of the determinants $(\mathrm{Hu}$ et al., 2016). In this background, the present study was aimed for the detection and characterization of ESBL and ACBL producing pathogenic E. coli strains (STEC) from diarrhoeic faecal samples of calves in West Bengal (India) followed by further characterization and to know their antibiotic resistance patterns in-vitro.

\section{Materials and Methods}

\section{Collection \& transportation of faecal samples}

Twenty-one faecal samples $(n=21)$ from bovine diarrhoea cases were aseptically collected from few private owners from Nadia district of West Bengal during April 2019. The faecal samples were collected directly into sterile vials with the sterile swabs from the rectum of the animals.

All the collected swabs were kept into the sterile peptone water (HiMedia, India) for transport. All the samples collected were placed on ice in a thermos flask with the proper label and were brought to the laboratory for further processing within $48 \mathrm{hrs}$ of collection.

\section{Isolation of Escherichia coli from faecal samples}

The peptone water (HiMedia, India) containing faecal samples were incubated at $37^{0} \mathrm{C}$ for overnight. After that, it was streaked onto MacConkey's agar (HiMedia, India) and again incubated at $37^{\circ} \mathrm{C}$ for overnight. Next day 2-3 rose pink colonies were randomly picked and transferred to EMB agar (HiMedia, India). The plates were incubated overnight at $37^{\circ} \mathrm{C}$. Next day colonies were observed and a single colony was streaked to nutrient agar (HiMedia, India) slant for further biochemical confirmation. 
Morphological and Biochemical identification

All the pure cultures were subjected to different morphological and biochemical tests as per methods described by Quinn et al., (2011).

\section{Detection of Escherichia coli by PCR}

\section{Bacterial DNA extraction}

For genotypic detection Escherichia coli, DNA was extracted from all the Escherichia coli isolates as per Mahanti et al., (2013).

Detection of Escherichia coli in the faecal sample by PCR

The morphologically and biochemically confirmed Escherichia coli isolates were subjected to PCR for genotype-based detection of the 16S $r R N A$ gene as described by Wang et al.(1996) with some modification.

\section{Detection of ESBL Property in Escherichia coli isolates}

Phenotypic Confirmatory Tests for ESBL Production

The antibiotic discs containing cefotaxime $(30 \mu \mathrm{g}$, HiMedia) and ceftazidime $(30 \mu \mathrm{g}$, HiMedia) with or without clavulanate $(10 \mu \mathrm{g}$, HiMedia) were used and a difference of $\geq 5$ $\mathrm{mm}$ between the zone diameters of either of the cephalosporin disks and their respective cephalosporin/clavulanate disk was considered to be phenotypically positive for ESBL propertyin the isolates(Bauer et al., 1966; Patel et al., 2015).

Detection of bla Genes in Escherichia coli isolates by PCR

Detection of $b l a_{\mathrm{CTX}-\mathrm{M}}, b l a_{\mathrm{TEM}}$ and $b l a_{\mathrm{SHV}}$ genesin phenotypically ESBL producing
Escherichia coli isolate by PCR assay was performed as per the protocol of Weill et al., (2004) and Cao et al., (2002) with some modification, respectively.

Detection of ACBL Production in Escherichia coli isolates

Phenotypic assays for detection of AmpC beta-lactamase in Escherichia coli isolates

All the Escherichia coli including ESBL producing isolates were subjected to cefoxitin- cloxacillin double-disc synergy (CC-DDS) test for phenotypic confirmation of ACBL property following the previously described protocol (Tan et al., 2009).

Detection of AmpC Gene in Escherichia coli isolates by PCR

Detection of $b l a_{\mathrm{AmpC}}$ genein phenotypically positive ACBL producing Escherichia coli isolates by PCR assay was performed as per the protocol of Fériaet al., (2002) with some modification.

Phenotypic assays for detection of carbapenemase and metallobeta-lactamase production in Escherichia coli isolates

All the Ertapenem intermediate ESBL producers were subjected to modified Hodge test (MHT) and combination disc diffusion test (CDDT) [IMP-10 $\mu \mathrm{g}$ and IMP-10 $\mu \mathrm{g}+$ EDTA-750 $\mu \mathrm{g}$ ] to confirm carbapenemase and Metallo beta-lactamase (MBL) production, respectively (Birgy et al., 2012).

Detection of Class I integrons in ESBL and ACBL producing Escherichia coli isolates

All the ESBL and ACBL producing Escherichia coli isolates from faecal samples were studied for the presence of class I integrons as per the previously described 
methods of Mazel et al., (2000) and BuffetBataillon et al., (2012) and with some modifications.

\section{Detection of Shiga toxin-producing} Escherichia coli (STEC) by multiplex PCR

All E.coli isolates including positive control were subjected to multiplex PCR for detection of any of the $s t x_{1}, s t x_{2}$, eaeA and ehxA genes considered for virulence factor of Shiga-toxin producing E.coli (STEC) as per the previously described protocol of Paton and Paton (1998, 2002).

\section{Antimicrobial Sensitivity test of the ESBL producing E. coli isolates}

Allthe ESBL producing isolates were tested for their sensitivity and resistance to different antimicrobials by the disc diffusion method (Bauer et al., 1966, Patel et al., 2015). The antibiotic discs used were Ertapenem $(10 \mu \mathrm{g})$, enrofloxacin $(5 \mu \mathrm{g})$, cefoperazone $(75 \mu \mathrm{g})$, cefoxitin $(30 \mu \mathrm{g})$, cefepime $(30 \mu \mathrm{g})$, gentamicin $(10 \mu \mathrm{g})$, tetracycline $(30 \mu \mathrm{g})$, amikacin (30 $\mu \mathrm{g}), \quad$ levofloxacin $(5 \mu \mathrm{g})$, ceftriaxone $(30 \mu \mathrm{g}), \quad$ ampicillin/sulbactam $(10 / 10 \mu \mathrm{g})$, ceftazidime $(30 \mu \mathrm{g})$, cefotaxime $(30 \mu \mathrm{g})$, ampicillin + cloxacillin $(10 \mu \mathrm{g})$, doxycycline hydrochloride $(30 \mu \mathrm{g})$ and amoxyclav $(30 \mu \mathrm{g})$.

Molecular characterization of isolated ESBL producing E. coli strains by Randomly amplified polymorphic DNAPCR (RAPD-PCR)

The molecular typing of all the ESBL producing isolates was done by RAPD-PCR using a primer (GTG) $)_{5}$ (GCC Biotech, India) in Gene Amp PCR system 9700 (Applied Biosystems, USA) as per previously described methods by described by Kar et al., (2015) with some modifications.

\section{Interpretation of the RAPD-PCR results}

All the images taken by the gel documentation system (UVP, UK) were analyzed by using the Doc-itLs image analysis software supplied with the system (UVP, UK) as per manufacturer's instruction. By comparing the difference in the RAPDPCR banding pattern phylogenetic relationship among the isolates were established. An unrooted phylogenetic tree was made by using the neighbour-joining method and dice similarity that is available in the software.

\section{Results and Discussion}

Colibacillosis is an economically important disease of bovines. This study was aimed to assess the risk factors associated with $E$. coli among diarrhoeic cattle.In the present study, $13(61.9 \%)$ bovine diarrhoeal faecal samples showed growth of the characteristic pinkcoloured colony in MacConkey agar and the isolates also produced 'metallic sheen' on EMB agar plates and all these isolates were presumptively considered as E. coli. Further characterization showed these were Gramnegative small rods and showed standard results of biochemical tests like Catalase (+ve), Oxidase (-ve), Urease (-ve), and Indole-Methyl Red-VogesProskauer-Citrate (+ + - -) [Quinn et al., 2011; Samanta, 2013]. All 13E. coliisolates were confirmed to be Escherichia coli in the $16 \mathrm{~S}$ rRNA gene PCRand this report is quite similar to the findings of Paul et al.(2010) who isolated $76 \%$ E. coli positivity from calf faecal samples. Other studies conducted by Masud et al., (2012), Dereje (2012), Taghadosi et al., (2018) and Mohammed et al., (2019) also detected 20(44\%), 25(43.1\%), 41(26.3\%) and $26(46.4 \%)$ E. coli isolates, respectively from bovine diarrhoeic faecal samples which showed a lower prevalence of $E$. coli than the present findings. Consideration of 2-3 rose 
pink colonies per sample in the present study is the probable reason for the higher occurrence.

During the detection of ESBL production phenotypically, $100 \%$ E. coli isolates were found to be positive for ESBL production (in combined disc diffusion assay) followed by confirmation of having at least one of the common ESBL genes (Klimiene et al., 2018). All the isolates harboured the $b l a_{\text {CTX-M }}(100 \%)$ whereas11(84.6\%) isolates possess bla $a_{\mathrm{SHV}}$ gene, however, none of the isolates possessed the $b l a_{\text {TEM }}$ gene (Table 1$)$. This study revealed that $b l a_{\text {СтX-м }}$ was the most prevalent gene followed by bla $a_{\mathrm{SHV}}$. The findings are corroborative with the reports of Geser et al., (2012) $\left[b_{\text {CTX-M }}-94 \%\right.$, bla $_{\mathrm{SHV}}-6 \%$, bla $_{\mathrm{TEM}^{-}}$ 0\%], Kar et al., (2015) [bla $\left.b l a_{\mathrm{SHV}}-94 \%, b_{\mathrm{TEM}}-50 \%\right]$ and Upadhyayet al., (2015)[bla СTХ-м $-56.3 \%$, bla $a_{\mathrm{SHV}}-9.7 \%$, $b l a_{\mathrm{TEM}}-12.6 \%$ ] who also reported CTX-M as the dominant ESBL genotype in E. coli isolates from different sources. ESBL positivity in $E$. coli isolates was also reported from different countries by Casella et al., (2017) and Maamar et al., (2016).No detection of bla $a_{\text {TEM }}$ gene in ESBL E. coli isolates was also supported by Geser et al., (2012).

The double-disc synergy using cefoxitincloxacillin (CC-DDS) test for phenotypic confirmation of ACBL production showed 11(84.6\%) isolates were AmpC producers and were confirmed to possess $b l a_{\mathrm{AmpC}}$ gene in PCR assay (Table 1). This high-level detection ACBL property in E. coli is almost matching with the reports of Vinueza-Burgos et al., (2019) [94.3\%], Banerjee and Acharyya (2020) [88.9\%] but quite higher than the reports of Kar et al., (2015) [11.1\%] and Casella et al., (2017) [4.2\%] maybe possibly due to geographical variation.

Table.1 Genotyping of ESBL and ACBL producing \& STEC E. coli strains isolated from bovine diarrhoeal faecal samples in West Bengal, India

\begin{tabular}{|c|c|c|c|c|c|c|c|c|}
\hline \multirow{3}{*}{$\begin{array}{c}\text { Sl. } \\
\text { No. }\end{array}$} & \multirow{3}{*}{$\begin{array}{c}\text { Detection } \\
\text { of STEC } \\
\text { gene } \\
(\text { eaeA })\end{array}$} & \multicolumn{3}{|c|}{ Phenotypic Detection of } & \multicolumn{4}{|c|}{ Molecular Detection of } \\
\hline & & \multicolumn{2}{|c|}{ ESBL property } & \multirow{2}{*}{$\begin{array}{c}\text { ACBL } \\
\text { property } \\
\text { DDCX }\end{array}$} & \multicolumn{3}{|c|}{ ESBL Genes } & \multirow{2}{*}{$\begin{array}{c}\text { ACBL } \\
\text { Gene } \\
\text { blampC }_{\text {Amp }}\end{array}$} \\
\hline & & DDCTX & DDCAZ & & bla $_{\text {CTXM }}$ & bla $_{\mathrm{TEM}}$ & $b_{\text {la }}$ & \\
\hline 1 & - & + & + & - & + & - & + & - \\
\hline 2 & + & + & + & + & + & - & + & + \\
\hline 3 & + & + & + & + & + & - & - & + \\
\hline 4 & - & + & + & + & + & - & + & + \\
\hline 5 & - & + & + & - & + & - & + & - \\
\hline 6 & + & + & + & + & + & - & + & + \\
\hline 7 & - & + & + & + & + & - & + & + \\
\hline 8 & + & + & + & + & + & - & - & + \\
\hline 9 & - & + & + & + & + & - & + & + \\
\hline 10 & - & + & + & + & + & - & + & + \\
\hline 11 & + & + & + & + & + & - & + & + \\
\hline 12 & + & + & + & + & + & - & + & + \\
\hline 13 & + & + & + & + & + & - & + & + \\
\hline
\end{tabular}


Table.2 Antibiogram of ESBL producing pathogenic E. coli strains isolated from bovine diarrhoea cases in West Bengal, India

\begin{tabular}{|c|c|c|c|c|c|c|c|}
\hline \multirow[t]{2}{*}{$\begin{array}{l}\text { Sl. } \\
\text { No. }\end{array}$} & \multirow[t]{2}{*}{$\begin{array}{l}\text { Antimicrobials } \\
\text { (Conc. in } \mu \mathrm{g})\end{array}$} & \multicolumn{2}{|c|}{ Isolates sensitive } & \multicolumn{2}{|c|}{$\begin{array}{c}\text { Isolates intermediately } \\
\text { sensitive }\end{array}$} & \multicolumn{2}{|c|}{$\begin{array}{l}\text { Isolates } \\
\text { resistant }\end{array}$} \\
\hline & & No. & $\%$ & No. & $\%$ & No. & $\%$ \\
\hline 1. & Amikacin (AK - 30) & 13 & 100 & 0 & 0 & 0 & 0 \\
\hline 2. & $\begin{array}{l}\text { Amoxicillin/Clavulanic acid (AMC - } \\
\text { 20/10) }\end{array}$ & 0 & 0 & 0 & 0 & 13 & 100 \\
\hline 3. & Ceftriaxone (CTR - 30) & 0 & 0 & 0 & 0 & 13 & 100 \\
\hline 4. & Ampicillin/Sulbactam (A/S-10/10) & 12 & 92.31 & 1 & 7.69 & 0 & 0 \\
\hline 5. & Doxycycline (DO - 10) & 12 & 92.31 & 1 & 7.69 & 0 & 0 \\
\hline 6. & Ceftazidime (CAZ - 30) & 0 & 0 & 0 & 0 & 13 & 100 \\
\hline 7. & Ertapenem (ETP - 10) & 1 & 7.69 & 12 & 92.31 & 0 & 0 \\
\hline 8. & Gentamicin (GEN - 10) & 13 & 100 & 0 & 0 & 0 & 0 \\
\hline 9. & Levofloxacin (LE - 5) & 13 & 100 & 0 & 0 & 0 & 0 \\
\hline 10. & Ampicillin/Cloxacillin (AX-10) & 0 & 0 & 0 & 0 & 13 & 100 \\
\hline 11. & Cefoxitin (CX - 30) & 0 & 0 & 2 & 15.38 & 11 & 84.62 \\
\hline 12. & Cefotaxime (CTX - 30) & 0 & 0 & 0 & 0 & 13 & 100 \\
\hline 13. & Tetracycline (TE - 10) & 5 & 38.46 & 0 & 0 & 8 & 61.54 \\
\hline 14. & Enrofloxacin (EX - 5) & 0 & 0 & 11 & 84.62 & 2 & 15.38 \\
\hline 15. & Cefepime (CPM - 30) & 0 & 0 & 0 & 0 & 13 & 100 \\
\hline 16. & Cefoperazone (CPZ - 75) & 0 & 0 & 0 & 0 & 13 & 100 \\
\hline
\end{tabular}

None of the Ertapenem intermediate isolates was positive for the production of carbapenemase and metallobeta-lactamase enzyme and was carrying the class I integrons as revealed in this study. This might be due to no use of carbapenems in the therapy of bovine diarrhoea or other clinical conditions in this study area. Transmission of ESBL/ACBL producing organisms is regulated by mobile genetic elements especially class 1 integrons. Sometimes class 1 integrons detected from animals and human ACBL/ESBL producing isolates are homologous which confirms their role in transmission (EFSA Panel on Biological Hazards, 2011). Absence of integrons in the present study indicated the low transmission possibilities of the isolates. Similarly, the absence of class 2 and 3 integrons was detected earlier in drug-resistant E. coli isolates (Huang et al., 2020).
Multiplex PCR assays (m-PCR) revealed that $7(53.8 \%)$ of the $E$. coli isolates were possessing one of the SETC genes, eaeA but no other genes were detected (Table 1) [Dastmalchi and Ayremlou, 2012]. In their study, Mohammed et al., (2019) also reported the presence of eaeA gene in few E. coli isolates and stx $x_{1}$ gene in only one isolate detected from bovine faecal samples but no stx $x_{2}$ and ehxA genes. Wani et al., (2003) reported the presence of STEC $(9.73 \%)$ possessing $s t x_{1}, s t x_{2}$ and eaeA from calf diarrhea cases from $\mathrm{J} \& \mathrm{~K}$, India which almost supports the findings of the current study. Shiga toxigenic E. coli possess the eaeA chromosomal gene which can produce intimin that causes the intimate attachment of the bacteria to the host cell aggravating their pathogenic property resulting into diarrhoea in young animals and also in human beings (Blanco et al., 2004; Abbasi et al., 2014). 
All the ESBL producing E.coli isolates showed almost similar resistance/sensitivity pattern except in their antibiogram. All the isolates were resistant to cefepime, amoxyclav, ceftriaxone, ampicillin + cloxacillin, cefoperazone, cefotaxime, and ceftazidime. However, no resistances were observed against levofloxacin, amikacin, ampicillin + sulbactum, gentamicin, and doxycycline (Table 2). High levels of antibiotic resistance, as shown in this report, were also detected earlier by Banerjee and Acharyya (2020), Ibrahim et al., (2016) and Hinthong et al., (2017). Ali et al., (2016) also found resistance against drugs like ampicillin (86.11\%), amoxicillin-clavulanic acid $(63.89 \%)$, cefotaxime $(100 \%)$, ceftazidime $(66.67 \%)$, tetracycline $(72.22 \%)$ and gentamicin $(61.11 \%)$ by ESBL E. coli pathogens in their study. Faruk et al., (2016) reported that ampicillin, cefotaxime, ceftazidime, and cefuroxime (all 100\%), tetracycline $(93.54 \%)$ were highly resistant but imipenem (100\%) to be highly sensitive to the ESBL E. coli strains isolated from cattle in their study which almost matches with the current findings. Resistance profile of the $E$. coli isolates in the present study reflected the usage pattern of antibiotics in the studied animals.

All the 13 ESBL producing strains were typed by RAPD-PCR using GTG5 gene to determine the genetic relationship among the strains. In RAPD-PCR, it was evident that the banding patterns of the isolates were the same with amplified fragment size ranging from $375 \mathrm{bp}$ to $1500 \mathrm{bp}$ was produced.

The phylogenetic analysis of ESBL producing strains after RAPD-PCR revealed that there are no differences among the isolates and was belonged to similar origin (data not shown). All isolates might come from the same type of infection and therefore possess similar genetic characters. These were also reported by Lim et al., (2009)and Kar et al., (2015) in their studies. The findings of Radu et al., (2001) and Johnson et al., (2003) are more or less similar to the current observations too.

The study, therefore, can be concluded as approx. 62\% faecal samples from bovines diarrhoea cases screened in this study were positive for $E$. coli. All the isolates were positive to ESBL property with presence of bla $a_{\mathrm{CTX}-\mathrm{M}}(100 \%)$ and $b l a_{\mathrm{SHV}}(84.6 \%)$ genes. Approx. $84.6 \%$ E. coli isolates were positive for ACBL property with presence of bla $a_{\mathrm{AmpC}}$ gene. Pathogenic STEC gene (eaeA) was detected in approx. $54 \%$ E. coli strains found in this study which quite significantly is matching with the bovine diarrhoea outcomes.

The pathogenic E. coli isolates with ESBL property were quite resistant to many commonly used antimicrobials but few drugslike levofloxacin, amikacin, ampicillin + sulbactam, gentamicin, and doxycycline were effective against these pathogens in-vitro. These drug-resistant STECs may be of great clinical significance as these can easily create animal health hazards due to unsuccessful treatment with common antimicrobials and may be zoonotic too in few cases.

\section{Acknowledgements}

The authors thank the University Authorities and the Faculties of Department of Veterinary Microbiology, West Bengal University of Animal and Fishery Sciences, West Bengal, India for providing necessary funds, research facilities and support for this study. They are also thankful to the animal owners and dairy farmers for their field supports.

\section{Conflict of Interest}

The authors declare that there is no competing interest among the authors. 


\section{References}

Abbasi P., Kargar M., Doosti A., Mardaneh J., Ghorbani-Dalini S., Dehyadegari M.A. 2014.Characterization of Shiga-toxin producing $E$. coli (STEC) and enteropathogenic $E$. coli (EPEC) using multiplex Real-Time PCR assays for st $x_{1}$, $s t x_{2}$, eaeA. Iran. J. Microbiol., 6(3): 169174.

AchaS. J., Kuhn I., Jonsson P., Mbazima G., Katouli M., Mollby R.S.2004. Studies on calf diarrhoea in Mozambique: prevalence of bacterial pathogens. Acta Vet. Scand., 45: 27-36.

Acres S.D.1985. Enterotoxigenic Escherichia coli infections in newborn calves: a review. J. Dairy Sci., 68: 229-256.

Ali T., ur Rahman S., Zhang L., Shahid M., Zhang S., Liu G., Gao J., Han B.2016. ESBL-Producing Escherichia coli from Cows Suffering Mastitis in China Contain Clinical Class 1 Integrons with CTX-M Linked to ISCR1. Front.Microbiol., 7: 1931.

Banerjee A., Acharyya S. 2020. Molecular characterization of STEC isolated from Ducks and its relation to ESBL production. Ukr. J. Vet. Agri. Sci., 3(2): 24-29.

Bauer A.W., Kirby W.M., Sherrris J.C., Turck M. 1966. Antibiotic susceptibility testing by a standardized single disk method. Am. J.Clin.Pathol., 45(4): 493-496.

Birgy A., Bidet P., Genel N., Doit C., Decre D., Arlet G.,Bingen E.2012.Phenotypic Screening of Carbapenemases and Associated $\quad \beta$-Lactamases in Carbapenem-Resistant

Enterobacteriaceae. J.Clin.Microbiol., 50(4): 1295-1302.

Blanco M., Blanco J.E., Mora A., Dahbi G., Alonso M.P., Gonzalez E.A., Bernardez M.I., Blanco J. 2004. Serotypes, virulence genes, and intimin types of Shiga toxin (verotoxin)-producing Escherichia coli isolates from cattle in Spain and identification of a new intimin variant gene (eae-xi). J.Clin.Microbiol.,
42(2): 645-651.

Buffet-Bataillon S., Le Jeune A., Le Gall-David S., Bonnaure-Mallet M., JolivetGougeon A.2012. Molecular mechanisms of higher MICs of antibiotics and quaternary ammonium compounds for Escherichia coli isolated from bacteraemia. J. Antimicrob. Chemother., 67(12): 2837-2842.

Bumunang E.W., McAllister T.A., RahatZaheer R., Polo R.O., Stanford K., King R., Niu Y.D.,Ateba C.N.2019.Characterization of Non-O157 Escherichia coli from Cattle Faecal Samples in the North-West Province of South Africa. Microorganisms, 7: 272, 19 pages.

Cao V., Lambert T., Nhu D.Q., Loan H.K., Hoang N.K., Arlet G., Courvalin P. 2002.Distribution of extended-spectrum $\beta$-lactamases in clinical isolates of Enterobacteriaceae in Vietnam. Antimicrob agents Chemother., 46(12):3739-3743.

Casella T., Nogueira M.C.L., Saras E., Haenni M., Madec J.Y. 2017. High prevalence of ESBLs in retail chicken meat despite reduced use of antimicrobials in chicken production, France. Int. J. Food Microbiol., 257: 271-275.

Cho Y., Kim W., Liu S., Kinyon J.M., Yoon K.J. 2010. Development of a panel of multiplex real-time polymerase chain reaction assays for simultaneous detection of major agents causing calf diarrhoea in faeces. J. Vet. Diagn. Invest., 22: 509-517.

Cho Y., Yoon K.J.2014.An overview of calf diarrhoea-infectious etiology, diagnosis, and intervention. J. Vet. Sci., 15(1): 117.

Dastmalchi S.H., Ayremlou N. 2012. Characterization of Shiga toxinproducing Escherichia coli (STEC) in faeces of healthy and diarrheic calves in Urmia region, Iran. Iran. J. Microbiol., 4(2): 63-69.

Dereje W.2012.Isolation and identification of Enterobacteria species from diarrheic calves in and around Addis Ababa, 
Ethiopia.6(1): 2474-7637.

EFSA Panel on Biological Hazards. 2011. Scientific Opinion on the public health risks of bacterial strains producing extended- spectrum $\quad \beta$ - lactamases and/or AmpC $\beta$ - lactamases in food and food- producing animals. EFSA J.,9(8): 2322.

Faruk P., Hulya T., Dilek O., Hakan Y. 2016. Molecular Characterization of ESBLproducing Escherichia coli isolated from Healthy Cattle and Sheep. Acta. VetBeograd., 66(4): 520-533.

Feria C., Ferreira E., Correia J.D., Goncalves J.,Canica M.2002. Patterns and mechanisms of resistance to beta-lactams and beta-lactamase inhibitors in uropathogenic Escherichia coli isolated from dogs in Portugal. J. Antimicrob. Chemother., 49: 77-85.

Geser N., Stephan R., Hachler H.2012.Occurrence and characteristics of extended-spectrum $\beta$-lactamase (ESBL) producing Enterobacteriaceae in foodproducing animals, minced meat and raw milk. BMC Vet. Res., 8(3): 21. doi: 10.1186/1746-6148-8-21.

Hickey C.D., Sheehan J.J., Wilkinson M.G., Auty M.A.E.2015. Growth and location of bacterial colonies within dairy foods using microscopy techniques: a review. Front.Microbiol., 6: $99 . \quad$ doi: 10.3389/fmicb.2015.00099.

Hinthong W., Pumipuntu N., Santajit S., Kulpeanprasit S., Buranasinsup S., Sookrung N., Chaicumpa W., Pisinee Aiumurai P., Indrawattana N.2017. Detection and drug resistance profile of Escherichia coli from subclinical mastitis cows and water supply in dairy farms in Saraburi Province, Thailand. Peer J., 5: e3431; doi 10.7717/peerj.3431.

Hu Y., Yang X., Li J., Lv N., Liu F., Wu J., Lin I.Y.C., Wu N., Weimer B.C., Gao G.F., Liu Y., Zhu B. 2016.The transfer network of bacterial mobile resistome connecting animal and human microbiome. Appl. Environ.Microbiol., 82: 66726681 .
Huang J., Lan F., Lu Y., Li B. 2020. Characterization of Integrons and Antimicrobial Resistance in Escherichia coli Sequence Type 131 Isolates. Can. J. Infect. Dis. Med. Microbiol., Article ID 3826186, 8 pages. https://doi.org/10.1155/2020/3826186.

Ibrahim D.R., Dodd C.E.R., Stekel D.J., Ramsden S.J.,Hobman J.L. 2016. Multidrug-resistant, extended-spectrum $\beta$-lactamase (ESBL)-producing Escherichia coli isolated from a dairy farm. FEMS Microbiol. Eco., 92: 1-13.

Izzo M.M., Kirkland P.D., Mohler V.L., Perkins N.R., Gunna A.A., House J.K. 2011. Prevalence of major enteric pathogens in Australian dairy calves with diarrhoea. Aust. Vet. J., 89(5): 167-173.

Johnson J.R., Murray A.C., Gajewski A., Sullivan M., Snippes P., Kuskowski M.A., Smith K.E.2003.Isolation and molecular characterization of nalidixic acid-resistant extraintestinal pathogenic Escherichia coli from retail chicken products. Antimicrob. Agents Chemother., 47(7): 2161-2168.

Kaper J.B., Nataro J.P., Mobley H.L.2004.Pathogenic Escherichia coli.Nat. Rev. Microbiol., 2: 123-140.

Kar D., Bandyopadhyay S., Bhattacharyya D., Samanta I., Mahanti A., Nanda P.K., Mondal B., Dandapat P., Das A.K., Dutta T.K., Bandyopadhyay S.,Singh R.K.2015. Molecular and phylogenetic characterization of multidrug-resistant extended-spectrum beta-lactamaseproducing Escherichia coli isolated from poultry and cattle in Odisha, India. Infect. Genet. Evol., 29: 82-90. doi:10.1016/j.meegid.2014.11.003.

Klimiene I., Virgailis M., Kerziene S., Siugzdiniene R., Mockeliunas R., Ruzauskas M.2018. Evaluation of genotypical antimicrobial resistance in ESBL producing Escherichia coli phylogenetic groups isolated from retail poultry meat. J. Food Safety, 38: e12370 (https:// doi. org/10. 1111/jfs.12370).

Lim K.T., Yasin R., Yeo C.C., Puthucheary 
S.,Thong K.L. 2009. Characterization of multidrug-resistant ESBL-producing Escherichia coli isolates from hospitals in Malaysia. J.BioMed.Biotechnol., 165637. doi:10.1155/2009/165637.

Maamar E., Hammami S., Alonso C.A., Dakhli N., Abbassi M.S., Ferjani S., Hamzaoui Z., Saidani M., Torres C.,Boubaker I.B.2016. High prevalence of extendedspectrum and plasmidic AmpC betalactamase-producing Escherichia coli from poultry in Tunisia. Int. J. Food Microbiol., 231: 69-75.

Mahanti A., Samanta I., Bandopaddhay S., Joardar S.N., Dutta T.K., Batabyal S., Sar T.K., Isore D.P.2013.Isolation, molecular characterization and antibiotic resistance of Shiga Toxin-Producing Escherichia coli (STEC) from buffalo in India.Lett. Appl. Microbiol., 56(4): 291298.

Masud M., Fakhruzzaman M., Nazir H. 2012.Isolation of E. coli from apparently healthy and diarrheic calves in Bangladesh and their antibiogram. J. Bang. Soc. Agric. Sci. Technol., 9: 4548.

Mazel D., Dychinco B., Webb V.A.,Davies J.2000. Antibiotic Resistance in the ECOR Collection: Integrons and Identification of a Novel Aad Gene. Antimicrob agents Chemother., 44(6): 1568-1574. doi: 10.1128/aac.44.6.15681574.2000.

Mohammed S.A., Marouf S.A., Erfana A.M., El-Jakee J.K., Hessain A.M., Dawoud T.M., Kabli S.A.,Moussa Ihab M. 2019. Risk factors associated with E. coli causing neonatal calf diarrhoea. Saudi J. Biol. Sci., 26(5): 1084-1088. doi: 10.1016/j.sjbs.2018.07.008.

Nguyen Y., Sperandio V. 2012. Enterohemorrhagic E. coli (EHEC) pathogenesis. Front Cell. Infect. Microbiol., 2(90): 1-7. doi: 10.3389/fcimb.2012.00090.

Patel J.B., Cockerill F.R., Bradford P.A., Eliopoulos G.M., Hindler J.A., Jenkins S.G., Lewis J.S., Limbago B., Miller
L.A., Nicolau D.P., Powell M., Swenson J.M., Traczewski M.M., Turnidge J.D., Weinstein M.P., Zimmer B.L.2015. Clinical and Laboratory Standard Institute: Performance Standards for Antimicrobial Susceptibility Testing; Twenty-Fifth informational supplement. CLSI document $\mathrm{M}_{100}-\mathrm{S}_{25}$. CLSI, Wayne, Pa, USA,35(3):1-240.

Paton A.W.,Paton J.C. 1998. Detection and Characterization of Shiga Toxigenic Escherichia coli by Using Multiplex PCR Assays for stxl, stx2, eaeA, Enterohemorrhagic E. coli hlyA, $r f b O 111$, and rfbO157. J.Clin. Microbiol., 36(2): 598-602.

Paton A.W., Paton J.C.2002.Direct Detection and Characterization of Shiga Toxigenic Escherichia coli by Multiplex PCR for stxl, stx2,eae, ehxA, and saa.J.Clin.Microbiol.,40(1): 271-274. doi: 10.1128/JCM.40.1.271-274.2002.

Paul, K., Khan, M.,Mahmud, S.2010.Isolation and characterization of $E$. coli from buffalo calves in some selected areas of Bangladesh. Bangl. J. Vet. Med., 8:2326.

Quinn P.J., Markey B.K., Leonard F.C., Fitz Patrick E.S., Fanning S.,Hartigan P.J.2011.In: Veterinary Microbiology and Microbial Diseases, $2^{\text {nd }}$ edn, Blackwell Publishing Ltd, 266-273.

Radu S., Ling O.W., Rusul G., Karim M.I.A., Nishibuchi M. 2001. Detection of Escherichia coli $\mathrm{O} 157$ : $\mathrm{H} 7$ by multiplex PCR and their characterization by plasmid profiling, antimicrobial resistance, RAPD and PFGE analyses. J. Microbiol. Meth., 46(2): 131-139.

Samanta I.2013. Chapter 6: Enterobacteriaceae, In: Veterinary Bacteriology, New India Publishing Agency, New Delhi, 119-135. Taghadosi R., Shakibaie M.R., Alizade H., Hosseini-Nave H., Askari A., Ghanbarpour R.2018. Serogroups, subtypes and virulence factors of Shiga toxin-producing Escherichia coli isolated from human, calves and goats in Kerman, Iran. Gastroenterol. Hepatol. 
Bed Bench, 11(1): 60-67.

Tan T.Y., Yong Ng L.S., He J., Koh T.H.,Hsu L.Y. 2009. Evaluation of Screening Methods to detect Plasmid-mediated AmpC in Escherichia coli, Klebsiella pneumoniae, and Proteus mirabilis. Antimicrob. Agents Chemother., 53(1): 146-149.

Tenover F.C., Mohammed M.J., Gorton T.S., Dembek Z.F. 1999. Detection and reporting of organisms producing extended spectrum-beta-lactamases: survey of laboratories in Connecticut. J. Clin. Microbiol., 37: 4065-4070.

Upadhyay S., Hussain A., Mishra S., Maurya A.P., Bhattacharjee A., Joshi S.R. 2015. Genetic Environment of Plasmid Mediated CTX-M-15 Extended Spectrum Beta-Lactamases from Clinical and Food-Borne Bacteria in NorthEastern India. PLoS One, 10(9): e0138056.

Vinueza-Burgos C., Ortega-Paredes D., Narváez C., De-Zutter L., Zurita J. 2019. Characterization of cefotaxime resistant Escherichia coli isolated from broiler farms in Ecuador. PLoS ONE, 14(4): e0207567.

https://doi.org/10.1371/journal.pone.020 7567.
Wang R., Cao W.,Cerniglia C.1996.PCR Detection and Quantitation of Predominant Anaerobic Bacteria in Human and Animal Fecal Samples. Appl. Environ.Microbiol.,62(4): 12421247.

Wani S.A., Bhat M.A., Samanta I., Nishikawa Y., Buchh A.S. 2003. Isolation and characterization of Shiga toxin- producing Escherichia coli (STEC) and enteropathogenic Escherichia coli (EPEC) from calves and lambs with diarrhoea in India.Lett. Appl. Microbiol., 37(2): 121-126

Weill F.X., Lailler R., Praud K., Kérouanton A., Fabre L., Brisabois A., Grimont A.D., Cloeckaert A. 2004. Emergence of extended-spectrum $\beta$-lactamase (CTXM-9)-producing multi-resistant strains of Salmonella enterica serotype Virchow in poultry and humans in France. J.Clin.Microbiol., 42(12): 5767-5773.

Yang G., Zhang S., Huang Y., Ye Q., Zhang J., Wu Q., Wang J., Chen M.,Xue L.2020. Isolation and Characterization of NonO157 Shiga Toxin-Producing Escherichia coli in Foods Sold at Retail Markets in China. J. Food Prot., 83(3): 460-466.

\section{How to cite this article:}

Kunal Batabyal, Achintya Mahanti, Samir Dey, Siddhartha Narayan Joardar, Indranil Samanta, Devi Prasad Isore, Abhiroop Banerjee and Abhishek Dharm Singh. 2020. Prevalence of Extended-spectrum and AmpC Beta-lactamases Producing STEC in Bovine Diarrhoea Cases in West Bengal, India. Int.J.Curr.Microbiol.App.Sci. 9(10): 100-110. doi: https://doi.org/10.20546/ijcmas.2020.910.014 